\title{
Language Learning Strategies (LLS) Instruction to Help Students Become Better Language Learners
}

\author{
Zandi Ernomo \\ Universitas Muhammadiyah Malang \\ E-mail: zandi@yahoo.com
}

Received: July 10, 2018

Accepted: August 17, 2018

Published: August 31, 2018

Doi: http://dx.doi.org/10.30587/jetlal.v2i2.2466

\begin{abstract}
Based on act of The Republic of Indonesia number 20, year 2003 on National Education System, learners should be active participants and able to develop their full potential. From the statement, the paradigm in educational field has changed from teacher centered learning to student-centered learning. Teaching language learners to learn so that they will be effective learners is a major issue in language teaching nowadays. A way to do that is by conducting strategy instruction. So, the purpose of this paper is to find out the definition of LLS, factors affecting the choice of LLS, classification of LLS, characteristics of LLS instruction, and models of LLS instruction.
\end{abstract}

Keyword : Language Learning Strategies, Help Students

A. Introduction

The definition of learning strategies may vary among experts. For example, Oxford (1990) defines learning strategies as learners particular actions or behavior when they are engaged in the process of learning. Meanwhile, Chamot (2004) and Liang (2009) argues that learning strategies include both mental and behavior. As Chamot (2004: pg. 15) illustrated:

" ... a learner could use selective attention (unobservable) to focus on the main ideas while listening to a newcast and could then decide take notes (observable) in order to remember the information."

It is not easy to judge whether learning strategies employed by students are mental or behaviour (Yang, 2010). Thus, Wood et al (2002) suggest that mind and motion cannot be divided since both of them were interrelated.

LLS has been researched by many scholars since the late of 70's (Lee, 2010) and affected by cognitive theory (Tseng, 2005; Ertmer \& Newby, 2013 ) which was popular in educational field from 1950s to 1980s. In cognitive learning theory, learners should be active during learning process as Ertmer \& Newby (2013) pointed out that “... emphasis on the active involvement of the learner in the learning process [learner control, metacognitive training (e.g self-planning, monitoring, and revising techniques)]."

A study on LLS is much influenced by Rubin's and Stern's research focusing on learning strategies applied by good language learners in the 70's (Fazeli, 2011). Since then, the theory has been developed by many experts (Zare, 2012) (see table 1).

Table 1.

Language Learning Strategies Classification

Researcher (s) and Year

1. Active task approach

Naiman et al (1978)

2. Realisation of language as a system

3. Realisation of language as a means of communication and interaction

4. Management of affective demands

5. Monitoring L2 performance 
1. Strategies that directly affect learning

Rubin (1981)

$>$ Clarification/ Verification

$>$ Monitoring

$>$ Memorisation

$>$ Guessing/Inductive Inferencing

$>$ Deductive Reasoning

$>$ Practice

2. Process that contribute indirectly to learning

$>$ Creates opportunities for practice

$>$ Production tricks

1. Cognitive strategies

Brown \& Palincar (1982)

2. Metacognitive strategies

3. Social-affective strategies

1. Cognitive strategies

O’Malley et al (1985)

2. Metacognitive strategies

3. Social-affective strategies

1. Direct strategies

Oxford (1990)

$>$ Memory strategies

$>$ Cognitive strategies

$>$ Compensation strategies

2. Indirect strategies

$>$ Metacognitive strategies

$>$ Affective strategies

$>$ Social strategies

Adopted from Lee, C.K., 2010. An Overview of Language Learning Strategies

Of all available classification of LLS, Oxford's taxonomy is widely used by many researchers (Chamot, 2004; Yang, 2010). Direct strategies are strategies that may be used by learners while learning something new in the class and indirect strategies are strategies employed by learners when thay are not indirectly involved in learning process. So far, most studies on language learning strategies focus on three major areas, such as; the characteristics of LLS, factors that influence LLS, and the experiment of learning strategies instruction (Fazeli, 2011). The characteristics of good language learners were stated in Rubin's study (1975). The conclusion of her study revealed some charateristics of good language learner that was pointed out by Lee (2010) 
"to be a willing and accurate guesser, to have a strong drive to communicate, to learn from communication, to be uninhibited and willing to make mistakes, paying attention to form by looking for patterns, taking advantage of every opportunity to practice, monitoring the speech of themselves and others, and focusing on meaning." (pg. 142)

Beside coducting a study focusing on the chararcteristics of good language learners, other researchers try to find out which factors that influence LLS. Liang (2009) extended the factors affecting the choice of strategies employed by language learners. Those factors include learner factors (e.g. learner belief, learning style, age, and motivation), situational factor (e.g. learning setting and learning task), social factor (e.g. gender), academic factor, and cultural background. Another major area of LLS research is the effect of LLS instruction. Chamot (2004) stated there were three models of LLS instruction, namely; Style and Strategy Based Instruction (SSBI), Cognitive Academic Language Learning Approach (CALLA), and Grenfell and Harris model. To find out the impact of LLS instruction, thus in the discussion part, this paper attempts to explore those models of LLS instruction.

\section{B. Discussion}

This section provides information about good characteristics of LLS instruction and models of LLS instruction. Iverson (2005) has mentioned some attributes of good LLS instruction model. The first characteristic is explicit. It means the model of LLS instruction should be able to raise the level of learner's awareness when using their own strategy use, suggested strategies from the teacher, and the used strategies applied by their classmates in tyhe class (Cohen, 1998). Then, the second characteristic of good strategy instruction is integrated and task based. It is much more effective if strategy instruction is inserted into regular classroom activities, particularly in the form of completing tasks (Cohen, 1998). Basically the notion of 'integrated' is in line with the task based instruction (Wenden, 1995). She suggests that learner have to be aware of the task thay are dealing with. The students need to know the purpose of the task, type of the task, their experience in completing the task, how to complete it, the required skill/s and knowledge to complete the task, and the strategies to complete the task. The third characteristic is individualized. Every learners have their own need; therefore, one strategy may be suitable for some learners while the others may feel uncomfortable using such strategy. To assist learners using variety of strategies in a different context or situation, teacher need to provide information about a range of strategies so that learners have their own decision to choose particular strategies that suit them (Cohen, 1998). Furthermore, teachers can also exploit or highlight some strategies that have been familiarized by learners when completing particular tasks. (Oxford et al, 1990).

The next attribute is strategy instruction has close relation with affective factors. Some affective factors that influence strategy instruction are emotions, attitudes, belief, and motivation (oxford, 1990). The last characteristic is the potential of strategy instruction in developing learner autonomy. If learners gains control over their own learning process, they can be an effective learners in term of thinking of some strategies to use when dealing with the given task (Rubin, 1987).

Those characteristics should be integrated into all models of strategy instruction. There are some well-known models, for example; Style and Strategies-Based Instruction or SSBI developed by Cohen (1998), Chamot's et al model (1999) CALLA or Cognitive Academic Language Learning Approach, and Grenfell and Harris's model (1999). Those models of strategy instructions share some common ideas. Chamot (2004) stated that:

"All agree on the importance of developing student's metacognitive understanding of the value of learning strategies and suggest that this is facilitated through teacher demonstration and modeling. All emphasize the importance of providing multiple practice opportunities with the strategies so that studens can use them autonomously. All suggest that students shouul evaluate how well a strategy has worked, choose strategies for a task, and actively transfer strategies to new task."

Moreover, those models consist of several components in which the principle is lied. For instance, SSBI (Cohen, 2005) has five components in it, such as; strategy preparation, strategy awareness raising, strategy training, strategy practice, and personalization strategies. First, strategy preparation refers to understanding current strategies used by the learners and to measure how far they use it when dealing with some tasks. Second, strategy awareness means communicating the general student's awareness after completing SSBI tasks. What the teacher can do at this phase is giving information to the learners about (1) the description of learning process, (2) students preferred learning style and particular general approach when they deal with the SSBI tasks, (3) learning strategies employed by learners themselves, their classmates, as well as suggested strategies from the teacher, (4) learners responsibility during completing the tasks, (5) some ways for evaluating the effectiveness of their strategies. Third, strategy instruction illustrates teacher's demonstration and model of suitable strategies to be used. Next, strategy practice means designing an activity in which learners can practice the discussed strategies. Finally, personalization strategy refers to evaluation of the used strategies done by the learners under teacher's direction and encourage learners to look at the possibility of using the strategies in other context. 
The components CALLA (Chamot, 1999) consist of preparation, presentation, practice, self-evaluation, expansion, and assesment. Iverson (2005) has mentioned the preparation phase as pre-assessment phase. The purpose of it is to familiarize the concept of LLS and to assist student in realizing their own strategy use (Iverson, 2005). This can be done through administering SILL or The Strategy Inventory for Language Learning which is developed by Oxford. Such instrument is widely used by many researchers because it is available on many languages (Mistar and Umamah, 2014). During presentation phase, teacher explains new strategies, demonstrates how to use those strategies for completing certain task, and names those strategies so that learners are able to remember them (Chamot, 2004). In the third phase, practice, learners are given a chance to use the targeted strategies. Teachers in this phase should be able to design a moderate level activity, which is not too easy nor difficult and is in line with or integrated with the existing syllabus or curriculum. (Oxford et al, 1990). Learners evaluate their own strategies afterward (Iverson, 2005). If learners gain control over appropiate strategies during learning process, teachers can encourage the learners to use such streatgies in other context. This phase is called expansion (Oxford et al, 1990). Finally, teacher assesses the student's effort in using strategies in learning (Chamot, 2004)

As for Grefell and Harris (1999), this model is made up of six steps. The first step is awareness raising. In this step, learners try to finish particular task. When they are finished, teacher makes conclusion about the strategies used by learners. The next step is modelling. The teacher's role in this step is demonstrating possible strategies for learners and discussing those strategies with students. Afterward, the learners are given different task and asked to practice the new strategies. Then, in action planning and focused practice, learners are taught to select suitable strategies to assist in understanding particular obstacles and then learners do the action using selected strategies. Finally, teacher and learner make evaluation.

To conclude, all models of strategy instruction concern to develop learner's mental process in term of determining potential strategies in completing particular tasks, learner's self evaluation about the used strategies, and some possible ways in term of encouraging learners to use strategies during learning process so that their proficiency in language learning will improve (Chamot, 2004)

\section{Conclusion}

Conducting strategy instruction is worth trying idea in language teaching since it assists language learners become effective and better students. Moreover, the Indonesian system of education which emphasizes on making learners to be active participant in every learning process is in line with the principle of strategy instruction.

\section{Referrences}

Chamot, A.U, 2004. Issues in Language Learning Strategy Research and Teaching. Electronic Journal of Foreign language Teaching Vol.1, No. 1, pp. 14-26. National University of Singapore.

Cohen, A. D., 1998. Strategies in Learning and Using A Second Language. Harlow, England: Longman.

Ertmer, P. A., Newby, T. J., 2013. Behaviorism, Cognitivism, Constructivism: Comparing Critical Features From an Instructional Design Perspective. Performance Improvement Quarterly, 26(2) pp. 43-71. DOI: 10.1002/piq. 21143

Fazeli, S. H., 2011. The Exploring Nature of Language Learning (LLSs) and Their Relationship with Various Variables with Focus on Personality Traits in the Current Studies of Second/Foreign Language Learning. Theory and Practice in Language Studies, Vol. , No. 10, pp. 1311-1320. ISSN 1799-2591. doi: 10.4304/tpls.1.10.1311-1320. Dept., of Linguistics, University of Mysore, India.

Iverson, K. J. E., 2005. The Instruction of Language Learning Strategies for Low Proficiency ESL Learners. Unpublished Thesis. Hamline University. Saint Paul, Minnesota.

Lee, C. K., 2010. An Overview of Language Learning Strategies. ARECLS Vol. 7, 132-152.

Liang, T, 2009. Language Learning Strategies---The Theoretical Framework and Some Suggestions for Learner Training Practice. Retrieved from English www.ccsenet.org/journal.html. Language Teaching Journal Vol. 2 , No.4

Mistar, J., Umamah, A., 2014. Strategies of Learning Speaking Skill by Indonesian Learners of English and Their Contribution to Speaking Proficiency. TEFLIN Journal Vol. 25, No. 2.

Oxford, R. L., 1990. Language Learning Strategies: What Every Teacher Should Know. Boston: Heinle \& Heinle.

Oxford, R. L., Crookall, D., Cohen, A., Lavine, R., Nyikos, M., \& Sutter, W. (1990). Strategy training for language learners: Six situational case studies and a training model. Foreign Language Annals, 22 (3), 197-216.

Oxford, R. L, 2003. Language Learning Styles and Strategies: An Overview. GALA.

Rubin, J. What the Good Language Learner Can Teach Us. TESOL Quarterly, 9 (1), 41-51.

Tseng, S. F., 2005. Language Learning Strategies in Foreign Language Education. WHAMPOA-An Interdisciplinary Journal 49, 321-328. Department of Applied Foreign Language, Cheng Shiu University.

Wenden, A, L., 1995. Learner Training in Context: A Knowledge Based Approach. 23 (2). 183-194

Wood, W., Quinn, J. M., Kashy, D. A, 2002. Habits in Everyday Life: Thought, Emotion, and Action. Journal of Personality and Social Psychology Vol. 83, No. 6, 1281-1297. The American Psychological Association, Inc. 
Yang, M., 2010. Language Learning Strategies of English As A Foreign language University Students in Korea. Unpublished Dissertation. Department of Curriculum, Instruction, and Media Technology. Indiana State University. Terre Haute, Indiana.

Zare, P., 2012. Language Learning Strategies Among EFL/ESL Learners: A Review of Literature. International Journal of Humanities and Social Science Vol. 2, No. 5. Marvdasht Branch, Islamic Azad University, Iran. 